\title{
Biochemical and genetic evidence for the transfer of Enterococcus solitarius Collins et al. 1989 to the genus Tetragenococcus as Tetragenococcus solitarius comb. nov.
}

\author{
Saïd Ennahar ${ }^{1,2}$ and Yimin $\mathrm{Cai}^{1}$ \\ ${ }^{1}$ National Institute of Livestock and Grassland Science, Department of Animal Feeding and \\ Management, Nishinasuno, Tochigi 329-2793, Japan \\ ${ }^{2}$ Laboratoire de Chimie Analytique et Sciences de l'Aliment (UMR 7512), Faculté de \\ Pharmacie, Université Louis Pasteur, 74, route du Rhin, 67400 Illkirch, France
}

\begin{abstract}
Phylogenetic analysis of $16 \mathrm{~S}$ rRNA gene sequences revealed that Enterococcus solitarius is not a member of the genus Enterococcus, but is related to species of the genus Tetragenococcus. On a phylogenetic tree, E. solitarius clustered with Tetragenococcus halophilus and Tetragenococcus muriaticus, with which it showed the highest 16S rRNA gene sequence similarity level (about $94 \%$ ). Phenotypic studies indicated that $E$. solitarius was also unable to produce acid from lactose, providing further evidence of its affiliation to the genus Tetragenococcus. DNA hybridization studies indicated that E. solitarius was clearly a separate species, different from T. halophilus and T. muriaticus (reassociation levels of about 23 and $54 \%$, respectively). As suggested in previous studies, E. solitarius is closely related to but clearly distinct from $T$. halophilus. Based upon properties that taxonomically distinguish it from species of the genus Enterococcus, it is proposed that $E$. solitarius be transferred to the genus Tetragenococcus and reclassified as Tetragenococcus solitarius comb. nov. (type strain, $885 / 78^{\top}=$ ATCC $49428^{\top}=$ CCUG $29293^{\top}=$ CIP $103330^{\top}=\mathrm{DSM}^{\top} 534^{\top}=\mathrm{JCM} 8736^{\top}=\mathrm{LMG}^{\top}$ $12890^{\top}=$ NCTC $12193^{\top}$ ).
\end{abstract}

Enterococcus solitarius was first described by Collins et al. (1989) and isolated from a human sample. The only strain known to date - the type strain - was identified on the basis of conventional physiological tests, as described by Facklam \& Collins (1989). However, it was reported that strict adherence to these tests often led to misidentification of this particular species (Buschelman et al., 1993; Ruoff et al., 1990; Tsakris et al., 1998). With the use of 16 S rRNA gene sequences in phylogenetic analyses, it was suggested that E. solitarius may in fact not be an enterococcal species, since its 16S rRNA gene sequence is too different from those of other Enterococcus species for it to be included in this genus (Collins et al., 1990; Patel et al., 1998; Williams et al., 1991). More recently, while performing sequence analysis of the $16 \mathrm{~S}$ rRNA genes of lactic acid bacteria inhabiting paddy rice silage, we also noticed that $E$. solitarius was only

Published online ahead of print on 24 September 2004 as DOI 10.1099/ijs.0.63205-0.

The GenBank/EMBL/DDBJ accession number for the 16S rRNA gene sequence of Tetragenococcus solitarius DSM $5634^{\top}$ is AJ301840.

Results of DNA-DNA hybridization experiments are available as supplementary material in IJSEM Online. remotely related to other enterococci (Ennahar et al., 2003). Other studies based on enterococci-specific PCR assays (Ke et al., 1999) or on whole-cell-protein profiles (Barros et al., 2001) were consistent with 16S rRNA gene sequence data. In fact, phylogenetically, E. solitarius appears to be more closely related to members of the genus Tetragenococcus (Barros et al., 2001; Collins et al., 1990; Ke et al., 1999; Patel et al., 1998; Williams et al., 1991), and it has even been suggested that E. solitarius and Tetragenococcus halophilus may constitute a single taxon (Ke et al., 1999; Monstein et al., 2001). However, controversy still exists, since a more recent study based on the sequence of a highly specific fragment within the enterococcal superoxide dismutase gene clearly placed E. solitarius among enterococcal species (Poyart et al., 2000). A comparative investigation including Enterococcus species and Tetragenococcus species has yet to be carried out to establish whether E. solitarius is a miscategorized taxon.

In this study, the E. solitarius type strain JCM $8736^{\mathrm{T}}$ was analysed with respect to its $16 \mathrm{~S}$ rRNA gene sequence, DNA relatedness and phenotypic traits. In addition, T. halophilus JCM $5888^{\mathrm{T}}$ and Tetragenococcus muriaticus JCM $10006^{\mathrm{T}}$, and the type strains of closely related Enterococcus species 
Table 1. Acid production from carbohydrates by E. solitarius, Tetragenococcus species and closely related species

Taxa: 1, Enterococcus casseliflavus JCM $8723^{\mathrm{T}}$; 2, E. faecalis JCM 5803 ${ }^{\mathrm{T}}$; 3, E. gallinarum JCM $8728^{\mathrm{T}}$; 4, E. cecorum JCM $8724^{\mathrm{T}}$; 5, E. saccharolyticus JCM $8734^{\mathrm{T}}$; 6, E. solitarius JCM $8736^{\mathrm{T}}$; 7, T. halophilus JCM $5888^{\mathrm{T}} ; 8$, T. muriaticus JCM $10006^{\mathrm{T}}$. All of the strains were positive for hydrolysis of aesculin and acid production from $\mathrm{N}$-acetylglucosamine, D-fructose, D-glucose, D-mannose and salicin. None of the strains tested produced catalase or acid from adonitol, L-arabitol, erythritol, D-fucose, L-fucose, glycogen, 5-ketogluconate, D-lyxose, methyl xyloside, sorbose, L-xylose and xylitol. +, Positive; -, negative; $(+)$, weak or delayed reaction.

\begin{tabular}{|c|c|c|c|c|c|c|c|c|}
\hline Character & 1 & 2 & 3 & 4 & 5 & 6 & 7 & 8 \\
\hline Amygdalin & + & + & + & + & + & + & + & - \\
\hline L-Arabinose & + & - & + & + & - & - & + & - \\
\hline D-Arabitol & - & - & - & - & - & - & + & - \\
\hline Arbutin & + & - & + & + & + & + & + & - \\
\hline Cellobiose & + & + & + & + & + & + & + & - \\
\hline Dulcitol & - & - & - & - & - & + & - & - \\
\hline Galactose & + & + & + & + & + & + & + & - \\
\hline Gluconate & + & $(+)$ & + & $(+)$ & - & + & + & - \\
\hline Glycerol & + & + & - & - & - & - & - & - \\
\hline Inulin & $(+)$ & - & $(+)$ & + & + & - & - & - \\
\hline 2-Ketogluconate & - & $(+)$ & - & - & + & - & $(+)$ & - \\
\hline Lactose & + & + & + & + & + & - & - & - \\
\hline Maltose & + & + & + & + & + & + & + & - \\
\hline Mannitol & + & + & + & $(+)$ & + & + & - & + \\
\hline Melibiose & + & - & + & + & + & - & - & - \\
\hline Melezitose & $(+)$ & $(+)$ & - & + & + & + & - & - \\
\hline Methyl $\alpha$-D-glucopyranoside & $(+)$ & $(+)$ & $(+)$ & - & + & - & - & - \\
\hline Methyl $\alpha$-D-mannopyranoside & - & - & + & - & - & - & - & - \\
\hline D-Raffinose & $(+)$ & - & + & + & + & - & - & - \\
\hline Rhamnose & $(+)$ & - & + & - & - & - & - & - \\
\hline Ribose & + & + & + & + & - & - & + & + \\
\hline Sorbitol & - & + & - & - & + & - & - & - \\
\hline Starch & - & $(+)$ & $(+)$ & $(+)$ & + & - & - & - \\
\hline Sucrose & + & + & + & + & + & + & + & - \\
\hline D-Tagatose & - & + & + & - & - & + & - & - \\
\hline Trehalose & + & + & + & + & + & + & - & - \\
\hline D-Turanose & + & + & + & + & + & + & + & - \\
\hline D-Xylose & + & - & + & - & - & - & + & - \\
\hline
\end{tabular}

were included as references (Table 1). Maintenance and propagation of cultures have been described previously (Ennahar et al., 2003).

E. solitarius JCM $8736^{\mathrm{T}}$ was compared with the type strains of Tetragenococcus species and closely related Enterococcus species using carbohydrate assimilation/fermentation on API $50 \mathrm{CH}$ strips (bioMérieux), as described previously (Ennahar et al., 2003). Analyses of phenotypic features other than those analysed by the API system were performed as described by Cai et al. (1999). Our results indicate that, unlike other Enterococcus species, E. solitarius JCM $8736^{\text {T }}$ did not ferment lactose, which is a common trait of both members of the genus Tetragenococcus (Table 1). In addition, T. halophilus displayed the closest fermentation pattern to E. solitarius, with 18 identical reactions among the 28 differential carbohydrates tested. Both species produced acids from amygdalin, arbutin, cellobiose, galactose, gluconate, maltose, sucrose and trehalose, but not from glycerol, inulin, lactose, melibiose, methyl $\alpha$-D-glucopyranoside, methyl $\alpha$-D-mannopyranoside, D-raffinose, rhamnose, sorbitol or starch. The remaining carbohydrates yielded the same pattern of fermentation for all Enterococcus and Tetragenococcus species tested (Table 1).

Phylogenetic analysis based on 16S rRNA gene sequences was carried out. Amplification, purification and sequencing were performed as described previously (Ennahar et al., 2003). The almost-complete 16S rRNA gene sequences were determined for E. solitarius JCM $8736^{\mathrm{T}}$, T. halophilus JCM $5888^{\mathrm{T}}$ and T. muriaticus JCM $10006^{\mathrm{T}}$. These were identical to sequences determined by other investigators (see GenBank/EMBL/DDBJ accession numbers in Fig. 1). The highest levels of sequence similarity for E. solitarius were 


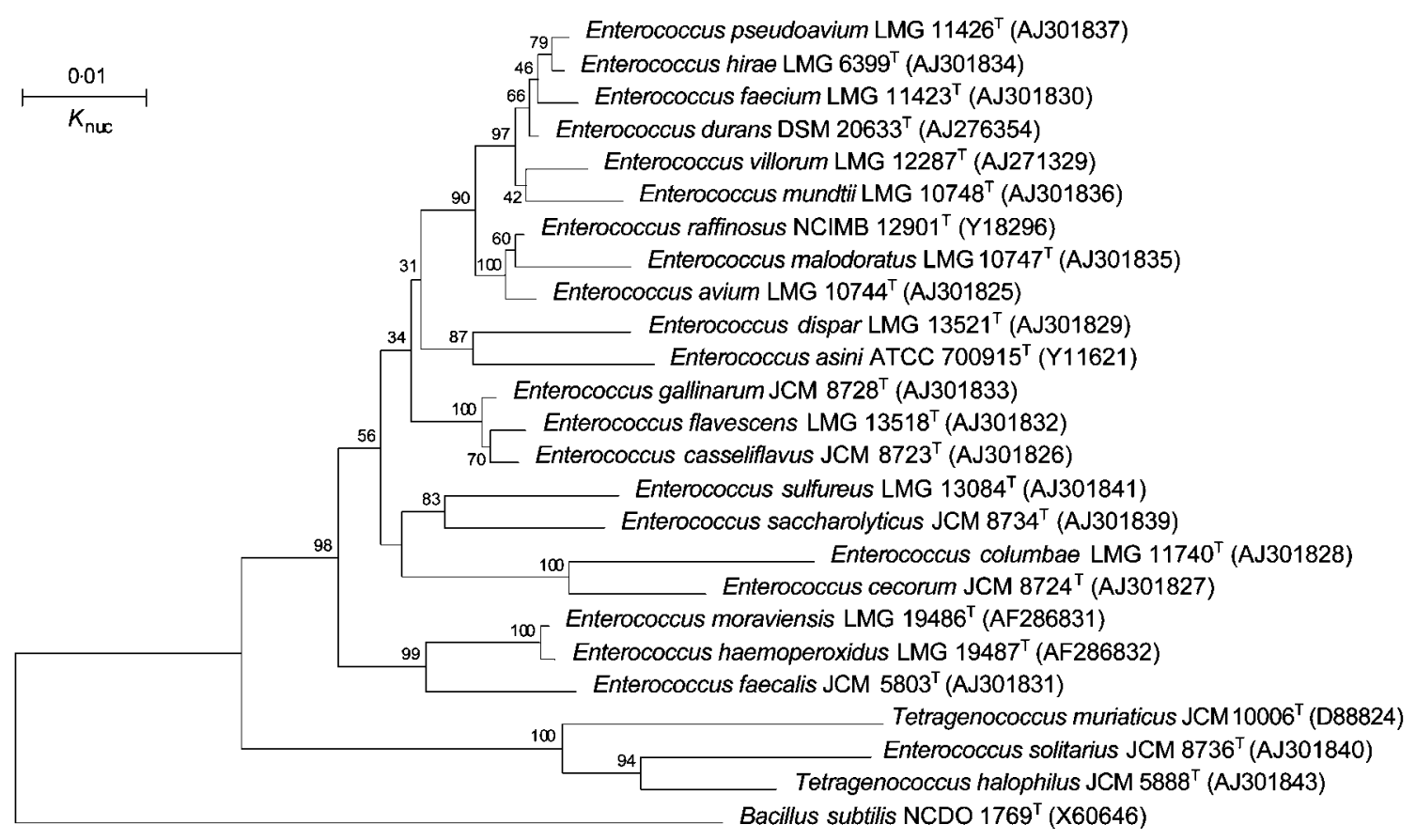

Fig. 1. Phylogenetic tree showing the relative positions of Enterococcus species and Tetragenococcus species as inferred by the neighbour-joining method with 16S rRNA gene sequences. Bootstrap values for a total of 100 replicates are shown at the nodes of the tree. References of the type strains used for comparison are given, as well as the GenBank/EMBL/ DDBJ accession numbers for all 16S rRNA gene sequences (in parentheses). Bacillus subtilis was used as an outgroup. Bar, $1 \%$ sequence divergence.

found with T. halophilus $(93 \cdot 8 \%)$ and T. muriaticus $(93.7 \%)$, with values similar to that obtained between the two Tetragenococcus species $(93 \cdot 8 \%)$. Similarity values between E. solitarius and other Enterococcus species were lower, generally ranging from about 88 to $90 \%$, while values between enterococci (except E. solitarius) ranged from about $95 \cdot 0$ to $99 \cdot 1 \%$.

Based on the 16S rRNA gene sequences, a phylogenetic tree was constructed by using the neighbour-joining method, as described previously (Ennahar et al., 2003). This analysis showed that E. solitarius formed a very well defined cluster with T. halophilus and T. muriaticus, with a bootstrap value of $100 \%$ supporting monophyly (Fig. 1). Among the two Tetragenococcus species, T. halophilus was the closest phylogenetic relative of E. solitarius in $94 \%$ of bootstrap analyses, which reflects a higher $16 \mathrm{~S}$ rRNA gene sequence similarity. The cluster making up the remaining enterococcal species was clearly distinct from the first one and was recovered in $98 \%$ of bootstrap analyses. This finding, along with the phenotypic data, is in agreement with previous reports suggesting a close phylogenetic relationship between $E$. solitarius and Tetragenococcus species (Barros et al., 2001; Ke et al., 1999; Patel et al., 1998; Williams et al., 1991).

The relatedness of the genomic DNAs of E. solitarius JCM $8736^{\mathrm{T}}$, T. halophilus JCM $5888^{\mathrm{T}}$ and T. muriaticus JCM $10006^{\mathrm{T}}$ was tested. Chromosomal DNA was purified by standard methods (Sambrook et al., 1989) as modified by Satomi et al. (1997). DNA-DNA hybridization experiments were performed by the method of Ezaki et al. (1989) using photobiotin labelling and colorimetric detection, as described previously (Ennahar et al., 2003). The results are presented in Table A, available as supplementary material in IJSEM Online. E. solitarius showed reassociation levels of $25 \cdot 7$ to $28 \cdot 6 \%$ with T. halophilus and $25 \cdot 4$ to $27 \cdot 2 \%$ with T. muriaticus. This is far lower than the DNA reassociation threshold value recommended for species delineation (70\%; Wayne et al., 1987). There were no great differences between the levels of homology measured when the genomic DNAs were used as targets or as probes. Therefore, as opposed to previous suggestions (Barros et al., 2001; Collins et al., 1990), E. solitarius constitutes a separate species, distinct from known Tetragenococcus species. On the other hand, DNA base composition, determined by HPLC as described previously (Ennahar \& Cai, 2004), showed the $\mathrm{G}+\mathrm{C}$ content for E. solitarius $(38 \cdot 3 \mathrm{~mol} \%)$ to be only slightly different from those of $T$. halophilus $(37 \cdot 0 \mathrm{~mol} \%)$ and T. muriaticus $(36.5 \mathrm{~mol} \%)$.

As described above, E. solitarius resembles Tetragenococcus species in its fermentative metabolism and 16S rRNA gene sequence. The low DNA-DNA reassociation values obtained for Tetragenococcus species clearly support the validity of E. solitarius as a separate Tetragenococcus species, with $T$. halophilus and T. muriaticus as its nearest 
phylogenetic relatives. Therefore, we conclude that $E$. solitarius (Collins et al., 1989) is a misclassified taxon that should be included in the genus Tetragenococcus as a separate species. The name Tetragenococcus solitarius comb. nov. is proposed.

\section{Description of Tetragenococcus solitarius comb. nov.}

Tetragenococcus solitarius (sol.i.tar.i' us. L. adj. solitarius alone, lonely).

Basonym: Enterococcus solitarius Collins et al. 1989.

Characteristics of the species are as described previously by Collins et al. (1989) with the following additions and corrections. Carbohydrate utilization pattern is as reported in Table 1 of this study. The DNA base ratio is about $38 \mathrm{~mol} \% \mathrm{G}+\mathrm{C}$ (as determined by HPLC). The GenBank/ EMBL/DDBJ accession number for the 16S rRNA gene sequence is $\mathrm{AJ} 301840$.

The type strain is $885 / 78^{\mathrm{T}}$ (=ATCC $49428^{\mathrm{T}}=\mathrm{CCUG}$ $29293^{\mathrm{T}}=\mathrm{CIP} 103330^{\mathrm{T}}=\mathrm{DSM} 5634^{\mathrm{T}}=\mathrm{JCM} 8736^{\mathrm{T}}=\mathrm{LMG}$ $12890^{\mathrm{T}}=$ NCTC $12193^{\mathrm{T}}$ ).

\section{References}

Barros, R. R., Carvalho, M. G. S., Peralta, J. M., Facklam, R. R. \& Teixeira, L. M. (2001). Phenotypic and genotypic characterization of Pediococcus strains isolated from human clinical sources. J Clin Microbiol 39, 1241-1246.

Buschelman, B. J., Bale, M. J. \& Jones, R. N. (1993). Species identification and determination of high-level aminoglycoside resistance among enterococci. Comparison study of sterile body fluid isolates, 1985-1991 Diagn Microbiol Infect Dis 16, 119-122.

Cai, Y., Kumai, S., Ogawa, M., Benno, Y. \& Nakase, T. (1999). Characterization and identification of Pediococcus species isolated from forage crops and their application for silage preparation. Appl Environ Microbiol 65, 2901-2906.

Collins, M. D., Facklam, R. R., Farrow, J. A. E. \& Williamson, R. (1989). Enterococcus raffinosus sp. nov., Enterococcus solitarius sp. nov. and Enterococcus pseudoavium sp. nov. FEMS Microbiol Lett 48, 283-288.

Collins, M. D., Williams, A. M. \& Wallbanks, S. (1990). The phylogeny of Aerococcus and Pediococcus as determined by $16 \mathrm{~S}$ rRNA sequences analysis: description of Tetragenococcus gen. nov. FEMS Microbiol Lett 70, 255-262.

Ennahar, S. \& Cai, Y. (2004). Genetic evidence that Weissella kimchii Choi et al. 2002 is a later heterotypic synonym of Weissella cibaria Björkroth et al. 2002. Int J Syst Evol Microbiol 54, 463-465.
Ennahar, S., Cai, Y. \& Fujita, Y. (2003). Phylogenetic diversity of lactic acid bacteria associated with paddy rice silage as determined by $16 \mathrm{~S}$ ribosomal DNA analysis. Appl Environ Microbiol 69, 444-451.

Ezaki, T., Hashimoto, Y. \& Yabuuchi, E. (1989). Fluorometric deoxyribonucleic acid-deoxyribonucleic acid hybridization in microdilution wells as an alternative to membrane filter hybridization in which radioisotopes are used to determine genetic relatedness among bacterial strains. Int J Syst Bacteriol 39, 224-229.

Facklam, R. R. \& Collins, M. D. (1989). Identification of Enterococcus species isolated from human infections by a conventional test scheme. J Clin Microbiol 27, 731-734.

Ke, D., Picard, F. J., Martineau, F., Ménard, C., Roy, P. H., Ouellette, M. \& Bergeron, M. G. (1999). Development of a PCR assay for rapid detection of enterococci. J Clin Microbiol 37, 3497-3503.

Monstein, H. J., Ahrné, S., Molin, G., Nikpour-Badr, S. \& Jonasson, J. (2001). Identification of enterococcal isolates by temperature gradient gel electrophoresis and partial sequence analysis of PCRamplified 16S rDNA variable V6 regions. APMIS 109, 209-216.

Patel, R., Piper, K. E., Rouse, M. S., Steckelberg, J. M., Uhl, J. R., Kohner, P., Hopkins, M. K., Cockerill, F. R., III \& Kline, B. C. (1998). Determination of $16 \mathrm{~S}$ rRNA sequences of enterococci and application to species identification of nonmotile Enterococcus gallinarum isolates. J Clin Microbiol 36, 3399-3407.

Poyart, C., Quesnes, G. \& Trieu-Cuot, P. (2000). Sequencing the gene encoding manganese-dependent superoxide dismutase for rapid species identification of enterococci. J Clin Microbiol 38, 415-418.

Ruoff, K. L., de la Maza, L., Murtagh, M. J., Spargo, J. D. \& Ferraro, M. J. (1990). Species identities of enterococci from clinical specimens. $J$ Clin Microbiol 28, 435-437.

Sambrook, J., Fritsch, E. F. \& Maniatis, T. (1989). Molecular Cloning: a Laboratory Manual, 2nd edn. Cold Spring Harbor, NY: Cold Spring Harbor Laboratory.

Satomi, M., Kimura, B., Mizoi, M., Sato, T. \& Fujii, T. (1997). Tetragenococcus muriaticus sp. nov., a new moderately halophilic lactic acid bacterium isolated from fermented squid liver sauce. Int J Syst Bacteriol 47, 832-836.

Tsakris, A., Woodford, N., Pournaras, S., Kaufmann, M. \& Douboyas, J. (1998). Apparent increased prevalence of high-level aminoglycoside-resistant Enterococcus durans resulting from false identification by a semiautomated software. J Clin Microbiol 36, 1419-1421.

Wayne, L. G., Brenner, D. J., Colwell, R. R. \& 9 other authors (1987). International Committee on Systematic Bacteriology. Report of the ad hoc committee on reconciliation of approaches to bacterial systematics. Int J Syst Bacteriol 37, 463-464.

Williams, A. M., Rodrigues, U. M. \& Collins, M. D. (1991). Intragenic relationships of enterococci as determined by reverse transcriptase sequencing of small-subunit rRNA. Res Microbiol 142, 67-74. 